\title{
PELAKSANAAN BIMBINGAN AGAMA ISLAM DALAM MENINGKATKAN KETENANGAN JIWA WARGA BINAAN DI LEMBAGA PERMASYARAKATAN KELAS II KOTA METRO
}

\author{
Hemlan Elhany \\ Institut Agama Islam Negeri Metro \\ Email: hemlanceraci@gmail.com
}

\begin{abstract}
Abstrak
Allah menurunkan agama lslam sehagai penuntun jalan bagi manusia agar mereka tidak mudah tersesat. Agama merupakan tolak ukur bagi seseorang untuk melakukan suatu perbuatan, karena di dalam agama terkandung aturan yang Allah berikan dalam menjalani hidup. Aturan tersehut bukan sebatas hubungan manusia dengan Allah, tetapi aturan hubungan antara manusia dan hubungan dengan lingkungannya. Gejalagejala tidak tenang jiwa seseorang adalah mudah cemas, takut, emosi yang meluapaluap dan tidak terkendali, sehingga ia tidak dapat bersahabat dengan diri sendiri ataupun dengan orang lain. Seseorang membutuhkan pembimbing dalam proses pengenalan diri dan agama. Dibutuhkan berbagai proses untuk mengenal agama Islam, yakni dengan bantuan pembimbing yang memberikan pemahaman yang dapat diterima oleh orang tersebut sehingga dijadikan acuan dalam hidup, Pembinaan keagamaan yang baik, secara teoritis akan melahirkan hasil binaan yang baik untuk manusia. Begitu pula pembinaan keagamaan pada narapidana wanita yang baik, juga akan melahirkan karakter narapidana baik bagi dirinya sendiri dan masyarakat. Akan tetapi, fenomena yang ditemukan masih ada juga sebagian dari mereka yang terjaring dalam kasus yang sama beberapa kali, yang nyata-nyata dilarang oleh norma-norma agama dan masyarakat berbagai alasan mereka kembali ke tindak kejahatan tersebut. Bimbingan agama Islam merupakan salah satu bimbingan yang tepat untuk Seseorang yang kurang mendapatkan ketenangan jiwa. Melalui bimbingan agama, seseorang akan mendapatkan ketenangan jiwa sehingga tindakannya dan perbuatan narapidana sesuai dengan Syariat Allah Swt.
\end{abstract}

Kata Kunci: Bimbingan, Keagamaan, Ketenangan Jiwa, dan Lapas

\begin{abstract}
Allah revealed the religion of Islam sehagai guiding the way for humans so that they are not easily lost. Religion is a benchmark for a person to perform an act, because the rules contained in the religion which God gives us in life. Tersehut rule is not limited to the human relationship with God, but the rules of the relationship between man and the relationship with the environment. The symptoms of restless soul of a person is prone to anxiety, fear, emotion meluapaluap and uncontrolled, so he can not be friends with ourselves or with others. A person in need of guidance in the process of self-knowledge and religion. It takes a variety of processes to get to know the religion of Islam, namely with the help of mentors who provide insights that
\end{abstract}


can be accepted by the person so referable in life, a good religious formation, theoretically will bear good results for the human target. Similarly, religious guidance on good women prisoners, prisoners will also bear the character of both for themselves and the community. However, a phenomenon found there are also some of them are caught in the same case several times, which clearly prohibited by the norms of religion and society are various reasons they returned to the crime. Guidance religion of Islam is one proper guidance for the person who lacks obtain peace of mind. Through religious guidance, someone will get peace of mind so that his actions and deeds of prisoners in accordance with the Shari'a of Allah.

Keywords: Guidance, Religious, Peace of Soul, and Prison

\section{A. Pendahuluan}

Manusia adalah makhluk paling sempurna yang Allah ciptakan dibandingkan dengan lainnya, karena manusia memiliki pikiran dan perasaan yang tidak dimiliki oleh makhluk lainnya. Allah menurunkan agama lslam sehagai penuntun jalan bagi manusia agar mereka tidak mudah tersesat. Agama merupakan tolak ukur bagi seseorang untuk melakukan suatu perbuatan, karena di dalam agama terkandung aturan yang Allah berikan dalam menjalani hidup. Aturan tersehut bukan sebatas hubungan manusia dengan Allah, tetapi aturan hubungan antara manusia dan hubungan dengan lingkungannya.

Gejala-gejala tidak tenang jiwa seseorang adalah mudah cemas, takut, emosi yang meluapaluap dan tidak terkendali, sehingga ia tidak dapat bersahabat dengan diri sendiri ataupun dengan orang lain. Seseorang membutuhkan pembimbing dalam proses pengenalan diri dan agama. Dibutuhkan berbagai proses untuk mengenal agama Islam, yakni dengan bantuan pembimbing yang memberikan pemahaman yang dapat diterima oleh orang tersebut sehingga dijadikan acuan dalam hidup, maka seseorang yang memiliki jiwa tenang terhindar dari gejala gangguan-gangguan jiwa. Menurut Wiryo Setiana bahwa manusia yang mempunyai kelainan jasmani dan mental, biasanya mereka memiliki perilaku abnormal seperti sosiapatik (tidak dapat menyesuaikan diri), penyimpangan sosial yang dapat melakukan hal-hal krimlnal atau melanggar aturan dan norma. Seseorang yang melanggar aturan dan norma seperti di Indonesia dapat dikenakan hukuman dan sanksi sesuai undang-undang yang telah ditetapkan. Seseorang yang telah terbukti bersalah Seperti judi, mencuri, membunuh, 
korupsi, dan tindakan kriminal lainnya akan mendapatkan hukuman dipenjara dan orang tersebut dikenal dengan sebutan narapidana atau warga binaan ${ }^{1}$.

Pembinaan keagamaan yang baik, secara teoritis akan melahirkan hasil binaan yang baik untuk manusia. Begitu pula pembinaan keagamaan pada narapidana wanita yang baik, juga akan melahirkan karakter narapidana baik bagi dirinya sendiri dan masyarakat. Akan tetapi, fenomena yang ditemukan masih ada juga sebagian dari mereka yang terjaring dalam kasus yang sama beberapa kali, yang nyata-nyata dilarang oleh norma-norma agama dan masyarakat berbagai alasan mereka kembali ke tindak kejahatan tersebut dikarenakan sebagai berikut:

1.Gangguan Psikis : (balas dendam, frustasi, petualangan, broken home, dll.)

2.Gangguan Ekonomi :(tekanan ekonomi keluarga, krisis moneter, dll.)

3.Gangguan Budaya :(lingkungan tempat tinggal, pelanggaran norma sosial atau budaya, pelanggaran norma agama, dll.) ${ }^{2}$

Banyak permasalahan dan menjadi konflik bagaimana untuk mengembalikan dan memulihkan kepercayaan diri, harga diri, harkat dan martabat para narapidana ke kehidupan masyarakat kelak dan layak, serta secara normatif sesuai dengan norma ajaran Islam, maka perlu didekati dengan sentuhan nilai-nilai agama Islam. Sejalan dengan ini, maka pembinaan keagamaan sangat berperan dalam rangka mempercepat proses rehabilitasi tersebut. Inti pelaksanaan pembinaan keagamaan adalah penjiwaan agama dalam hidupnya, Ia dibina sesuai dengan tingkat dan situasi psikologisnya. ${ }^{3}$

Misi Lapas Kelas II Metro melaksanakan pembinaan sekaligus mempersiapkan warga binaan agar siap kembali ke masyarakat dan menjadi manusia yang berperan aktif dalam pembangunan negara melalui program.

a. Pembinaan ronani (mental) dalam agama dan emosional.

b. Pembinaan keterampilan (soft skill) yang kebutuhan di masyarakat.

c. Perlindungan terhadap Hak Asasi Manusia bagi warga binaan.

d. Menjaga keamanan bagi masyarakat, petugas, dan warga binaan.

e. Menjadi Lapas yang akuntabel dan pelayanan prima bagi publik.

\footnotetext{
1 Wiryo Setiana, Patologi Sosial (Bandung: Mimbar Pustaka, 2012), h. 114.

2 Kartono, Psikologi Anak (Bandung: Alumni, 1982), h. 222.

${ }^{3}$ M. Arifin, Pokok-Pokok Pikiran Tentang Bimbingan Penyuluhan Agama (Jakarta: Bulan Bintang, 1977), h. 13.
} 
Adapun Rumusan Masalah dalam penelitian ini yaitu : Apa program bimbingan agama Islam di Lapas Kelas II Metro?, Bagaimana proses bimbingan Islam di Lapas Kelas II Metro?, Bagaimana hasil dari kegiatan bimbingan dengan sebelum mengikuti kegiatan bimbingan agama Islam di Lapas Kelas II Metro ?. Tujuan Penelitian yaitu : Untuk mengetahui program bimbingan agama Islam di Lapas Kelas II Metro. Untuk mengetahui proses bimbingan Islam di Lapas Kelas II Metro. Untuk mengetahui hasil dari kegiatan blmbingan dengan sebelum mengikuti kegiatan bimbingan agama Islam di Lapas Kelas II Metro. Kegunaan Penelitian yaitu: Manfaat teoretis dapat memberikan kontribusi pemikiran bagi kellmuan tentang cara memberikan bimbingan agama Islam mengenai proses, metode, dan materi yang akan diberikan kepada warga binaan di Lapas Kelas II Metro serta dapat menjadi salah satu karya ilmiah yang dapat menambah koleksi kepustakaan Islam dan bermanfaat bagi kalangan akademis pada khususnya serta masyarakat pada umumnya. Penelitian ini diharapkan memberikan manfaat dalam pelaksanaan bimbingan agama islam bagi peneliti mengenai proses, materi, dan metode di Lapas Kelas II Metro yang menghasilkan baik pada pemahaman dan kesadaran warga binaan. Penelitiaan ini dapat bermanfaat juga bagi Lapas Kelas II Metro sebagal bahan pertimbangan dalam pelaksanaan bimblngan agama Islam khususnya pada pembina pesantren Lapas dalam melaksanakan kegiatan bimblngan agama Islam guna meningkatkan kesadaran diri dalam beragama Islam terhadap warga binaan Lapas Kelas II Metro.

\section{B. Kajian Teori}

1. Bimbingan Agama Islam

Istilah bimbingaan merupakan alih bahasa dari istilah Inggris guidance. Dalam kamus bahasa Inggris guidance dikaitkan dengan kata asal guide, yang diartikan sebagai berikut; menunjukkan jalan (showing the way), memimpin (leading);menuntun (conducting); memberikan petunjuk (giving instruction); mengatur (regulating); mengarahkan (governing); memberikan nasehat (giving advice). ${ }^{4}$

Bimbingan agama Islam adalah "proses pemberian bantuan terhadap individu agar mampu hidup selaras dan serasi dengan ketentuan dan petunjuk Allah, sehingga

4 W.S. Winkel, Bimbingan Dan Konseling Di Institusi Pendidikan (Jakarta: Gramedia, 1997), h. 65. 
dapat mencapai kebahagiaan hidup di dunia dan akhirat. ${ }^{5}$ Bimbingan adalah salah satu dari berbagai tugas manusia dalam membina dan membentuk manusia yang ideal dengan menggunakan bahasa agama. Bahkan, bisa dikatakan bahwa bimbingan merupakan amanat yang diberikan Allah kepada semua Rasul dan Nabi-Nya. Dengan adanya amanat bimbingan inilah, maka mereka menjadi demikian berharga dan bermanfaat bagi manusia, baik dalam urusan agama, dunia, pemenuhan kebutuhan, pemecahan masalah dan banyak hal lainnya. Bimbingan akhirnya menjadi satu kewajiban bagi setiap individu muslim, khususnya para alim ulama6. Tujuan yang ingin dicapai melalui bimbingan agama Islam adalah tingkat perkembangan yang optimal bagi setiap individu sesuai dengan kemampuannya, agar dapat menyesuaikan dirinya terhadap lingkungan masyarakat. Sejalan dengan perkembangan zaman dan kemajuan teknologi, akanberkembang pula konsepsi bimbingan agama Islam, sehingga tujuan dari bimbingan itu juga akan mengalami perubahan, dari cara-cara yang sederhana, manual menjadi lebih komprehensif.

\section{Ketenangan Jiwa}

Kata ketenangan jiwa terdiri dari kata ketenangan dan jiwa. Sedangkan kata ketenangan itu sendiri berasal dari kata tenang yang mendapat sufiks ke-an. Tenang berarti diam tak berubah-ubah (diam tak bergerak-gerak); tidak gelisah, tidak rusuh, tidak kacau, tidak ribut, aman dan tenteram (tentang perasaan hati, keadaan dan sebagainya). Tenang, ketenteraman hati, batin, pikiran ${ }^{7}$, sedangkan jiwa adalah seluruh kehidupan batin manusia yang menjadi unsur kehidupan, daya rohaniah yang abstrak yang berfungsi sebagai penggerak manusia dan menjadi simbol kesempurnaan manusia (yang terjadi dari hati, perasaan, pikiran dan angan-angan). Kata ketenangan jiwa juga dapat diartikan sebagai kemampuan untuk menyesuaikan diri sendiri, dengan orang lain, masyarakat dan lingkungan serta dengan lingkungan di mana ia hidup, sehingga

7.

${ }^{5}$ Faqih, Rahim, and Aunur, Bimbingan Dan Konseling Dalam Islam (Yogyakarta: UII Press, 2001), h.

${ }^{6}$ Musfir, Konseling Terapi (Jakarta: Gema Insani, 2005), h. 16.

7 Tim Penyusun Kamus Pusat Pembinaan dan Pengembangan Bahasa, Kamus Besar Bahasa Indonesia (Jakarta: Balai Pustaka, 2004), h. 927. 
orang dapat menguasai faktor dalam hidupnya dan menghindarkan tekanan-tekanan perasaan yang membawa kepada frustasi ${ }^{8}$.

3. Warga Binaan (Narapidana)

Menurut Pasal 1 Angka 5 UU Nomor 12 Tahun 1995 Tentang Pemasyarakatan, bahwa Warga Binaan Pemasyarakatan adalah Narapidana, Anak Didik Pemasyarakatan, dan Klien Pemasyarakatan. Adapun Narapidana adalah terpidana yang menjalani pidana hilang kemerdekaan di Lembaga Pemasyarakatan (UU RI No. 12 Th. 1995 tentang Pemasyarakatan Pasal 1 ayat 7).

4. Lapas Kelas II Metro.

Lapas adalah singkatan dari Lembaga Pemasyarakatan adalah tempat untuk melaksanakan pembinaan narapidana dan anak didik pemasyarakatan (UU RI No. 12 Th. 1995 tentang Pemasyarakatan Pasal 1 ayat 2). Lapas Kelas II Metro ini beralamat: Jl.A.Yani No.213 Kel.Iringmulyo Kec. Metro Timur Kota Metro 34111， yang dihuni dihuni oleh 449 orang, Email: lapasmetro_pengaduan@yahoo.co.id, Telepon: 072541709

Untuk mendapat gambaran yang jelas dari judul dalam penelitian ini dan untuk menghindari kesalah pahaman dalam penafsiran, maka peneliti memandang perlu memberikan batasan arti dari beberapa istilah dalam judul penelitian ini.

\section{a. Bimbingan Agama Islam}

Bimbingan adalah arahan, tuntunan. Menurut Rachman Notowidjojo, dalam bukunya Salcha Hatras yang berjudul "Konsep Dasar Bimbingan dan Konseling", makna bimbingan adalah suatu proses pemberian bantuan kepada individu yang dilakukan secara terus menerus, supaya individu tersebut dapat memahami dirinya, sehingga ia sanggup mengarahkan diri dan bertindak wajar sesuai dengan tuntunan dan keadaan sekolah, lingkungan, keluarga dan masyarakat, dengan demikian mereka dapat mengecap kebahagiaan hidupnya serta dapat memberikan sumbangan yang berarti kapada kehidupan masyarakat umumny ${ }^{10}$. Menurut W.S. Winkel menyebutkan bahwa bimbingan berarti pemberian bantuan kepada orang atau sekelompok orang

\footnotetext{
8 Zakiah Daradjat, Kesehatan Mental (Jakarta: Gunung Agung, 2006), h. 11.

${ }_{9}^{9}$ Peter Salim and Yenny Salim, Kamus Bahasa Indonesia Kontemporer (Jakarta: Modern English Press, 1991), h. 205.

10 Salcha Hatras, Konsep Dasar Bimbingan Dan Konseling (Surakarta: FKIP UNS, 1999), h. 2.
} 
dalam membuat pilihan-pilihan secara bijaksana dalam mengadakan penyesuian diri terhadap tuntutan-tuntutan hidup. Bantuan itu bersifat psikis (kejiwaan), bukan pertolongan finansial, medis dan sebagainya. Dengan bantuan ini, seseorang akhirnya dapat mengatasi sendiri masalah yang dihadapinya sekarang dan menjadi lebih mampu untuk menghadapi masalah yang akan dihadapi kelak. ${ }^{11}$

Bimbingan menurut Stopps adalah suatu proses yang terus menerus dalam membantu perkembangan individu untuk mencapai kemampuannya secaramaksimal dalam mengarahkan manfaat yang sebesar-besarnya baik bagi dirinya maupun bagi masyarakat ${ }^{12}$. Sedangkan menurut Faylor bimbingan adalah bantuan kepada seseorang dalam proses pemahaman dan penerimaan terhadap kenyataan yang ada pada dirinya sendiri serta perhitungan(penilaian) terhadap lingkungan sosioekonominya masa sekarang dan kemungkinan masa mendatang dan bagaimana mengintegrasikan dua hal tersebut melalui pilihan-pilahan diri yang membawa pada keputusan hidup pribadi dan kedaya gunaan hidup ekonomi sosial.

Agama adalah kepercayaan kepada Tuhan, sifat-sifat serta kekuasaan-Nya dengan ajaran dan kewajiban-kewajiban yang berhubungan dengan kepercayaan itu ${ }^{13}$. Dalam pengertian yang sederhana agama adalah proses hubungan manusia yang dirasakan terhadap sesuatu yang diyakininya, bahwa itu lebih tinggi dari manusia ${ }^{14}$. Sedangkan Islam yaitu agama yang diajarkan oleh Nabi Muhammad SAW yang berpedoman pada kitab suci Al-Qur'an atas perintah Allah ${ }^{15}$. Namun umumnya ulama' mendefinisikan Islam adalah wahyu Allah yang disampaikan kepada Nabi Muhammad SAW untuk kebahagian umat manusia di dunia dan akhirat ${ }^{16}$.

Dari penjelasan di atas dapat disimpulkan bahwa bimbingan agama Islam adalah merupakan proses pemberian bantuan yang dilakukan secara terus menerus dan berkesinambungan untuk membina, membangun, mengembangkan serta membantu kepada seseorang atau sekelompok orang agar dapatmenyelesaikan

11 W.S. Winkel, Bimbingan Dan Konseling Di Sekolah (Jakarta: Gramedia, 1984), h. 20.

12 M. Arifin, Pokok-Pokok Pikiran Tentang Bimbingan Penyuluhan Agama, h. 31.

13 Peter Salim and Yenny Salim, Kamus Bahasa Indonesia Kontemporer, h. 18.

14 Zakiah Daradjat, Kesehatan Mental, h. 24.

15 Peter Salim and Yenny Salim, Kamus Bahasa Indonesia Kontemporer, h. 581.

16 Khoirudin Nasution, Pengantar Studi Islam (Yogyakarta: Academia, 2004), h. 2. 
permasalahan yang sedang dihadapinya serta dapat membuat pilihan-pilihan secara bijaksana dalam penyesuaian diri terhadap tuntutan-tuntutan hidup. Bantuan ini bersifat psikologis (kejiwaan) dan berdasar pada ajaran-ajaran agama Islam yang berpedoman pada Al-Qu'an dan Hadits.

Unsur-Unsur dalam Bimbingan Agama Islam:

1. Subyek

Subyek adalah pelaku pekerjaan, atau dalam hal ini adalah orang yang melaksanakan bimbingan agama Islam atau orang yang mempunyai kemampuan dalam menyampaikan maksud dan tujuan pelaksanaan bimbingan agama Islam terhadap narapidana. Untuk menjadi seorang konselor atau pembimbing harus memenuhi syarat-syarat sebagai berikut: a) Menaruh minat mendalam terhadap orang lain dan penyebaran. b) Peka terhadap sikap dan tindakan orang lain. c) Memiliki kehidupan emosi yang stabil dan obyektif. d) Memilikikemampuan dan dipercaya orang lain. e) Menghargai fakta. ${ }^{17}$

2. Obyek

Obyek yaitu yang menjadi sasaran atau yang dibin a(yang mendapat pembinaan), dalam hal ini yaitu para narapidana yang sekarang berada dalam lembaga pemasyarakatan II Metro Lampung.

\section{Materi}

Yang dimaksud dengan materi adalah semua bahan-bahan yang akan disampaikan kepada terbina. Jadi yang dimaksud materi di sini adalah semua bahan yang dapat dipakai untuk bimbingan agama Islam. Materi dalam bimbingan agama Islam yaitu semua yang terkandung dalam al-Qur'an yaitu: akidah, akhlak, dan hukum ${ }^{18}$, adapun materinya:

a. Aqidah atau Keyakinan.

\footnotetext{
${ }^{17}$ Singgih D Gunarsa, Konseling Dan Psikoterapi (Jakarta: Gunung Mulia, 1992), h. 64.

${ }_{18}$ M. Quraish Shihab, A-Qur'an: Fungsi Dan Peran Wahyu Dalam Kehidupan Masyarakat (Bandung: Mizan Pustaka, 2007), h. 303.
} 
Merupakan fundamen bagi setiap muslim, dalam arti menjadi landasan yang memberi corak serta arah bagi kehidupan seoarang muslim ${ }^{19}$. Aqidah adalah kepercayaan yang wajib diyakini kebenarannya oleh setiap muslim yang dirumuskan dalam ajaran "enam rukun Iman" yakni Iman kepada Allah, malaikat, kitab-kitab, para Nabi dan Rasul-Rasul-Nya serta hari akhir. ${ }^{20}$

b. Akhlak atau Moral.

Akhlak atau moral merupakan pendidikan jiwa agar seseoarang dapat bersih dari sifat-sifat yang tercela dan dihiasi dengan sifat-sifat yang terpuji. Menurut Imam Al-Ghozali dalam Ihya' Ulumuddin, akhlaq adalah sifat yang tertanam dalam jiwa dari padanya timbul perubahahn yang mudah tanpa memerlukan pertimbangan pikiran ${ }^{21}$

c. Hukum atau Syari'ah .

Hukum atau Syari'ah merupakan peraturan-peraturan yang disyariatkan oleh Allah untuk pegangan bagi umat manusia, baik secara terperinci maupun global. Dan juga mengatur hubungan antara makhluk dengan Tuhannya.Yaitu: 1.Ibadah yaitu aturan agama yang mengatur hubungan manusia dengan Tuhan, yang dirumuskan dalam "lima rukun Islam" yakni: Syahadat, Sholat, Puasa, Zakat dan Haji. Ibadah merupakan manifestasi iman umat Islam yang berpedoman pada Al-Qur'an dan Hadits dan kesepakatan Ulama (Ijma').

\section{b. Ketenangan Jiwa}

Kata ketenangan jiwa terdiri dari kata ketenangan dan jiwa. Sedangkan kata ketenangan itu sendiri berasal dari kata tenang yang mendapat sufiks ke-an. Tenang berarti diam tak berubah-ubah (diam tak bergerak-gerak); tidak gelisah, tidak rusuh, tidak kacau, tidak ribut, aman dan tenteram (tentang perasaan hati, keadaan dan sebagainya). Tenang, ketenteraman hati, batin, pikiran ${ }^{22}$, sedangkan jiwa adalah seluruh kehidupan batin manusia yang menjadi unsur kehidupan, daya rohaniah yang abstrak yang berfungsi sebagai penggerak manusia dan menjadi simbol kesempurnaan

${ }_{19}$ M. Mashur Amin, Metode Dakwah Islamiyah (Yogyakarta: Sumbangsih, 1980), h. 17.

${ }^{20}$ Nasrudin Razak, Dienul Islam (Bandung: Al-Maarif, 1996), h. 39.

${ }^{21}$ Ibid., h. 31. Indonesia, h. 927.

22 Tim P. 
manusia (yang terjadi dari hati, perasaan, pikiran dan angan-angan). Kata ketenangan jiwa juga dapat diartikan sebagai kemampuan untuk menyesuaikan diri sendiri, dengan orang lain, masyarakat dan lingkungan serta dengan lingkungan di mana ia hidup, sehingga orang dapat menguasai faktor dalam hidupnya dan menghindarkan tekanan-tekanan perasaan yang membawa kepada frustasi ${ }^{23}$.

\section{c. Warga Binaan}

Kegiatan untuk melakukan pembinaan Warga Binaan Pemasyarakatan berdasarkan sistem, kelembagaan, dan cara pembinaan yang merupakan bagian akhir dari sistem pemidanaan dalam tata peradilan pidana" 24 Maksudnya, pemasyarakatan sebagai bagian akhir dari proses peradilan pidana dan dalam melaksanakan pidananya diberi suatu pembinaan yang ditujukan terhadap narapidana sebagai Warga Binaan Pemasyarakatan

Menurut Pasal 1 Angka 5 UU Nomor 12 Tahun 1995 Tentang Pemasyarakatan, bahwa Warga Binaan Pemasyarakatan adalah Narapidana, Anak Didik Pemasyarakatan, dan Klien Pemasyarakatan. Adapun Narapidana adalah terpidana yang menjalani pidana hilang kemerdekaan di Lembaga Pemasyarakatan (UU RI No. 12 Th. 1995 tentang Pemasyarakatan Pasal 1 ayat 7).

\section{d. Lapas Kelas II Metro}

Lembaga Pemasyarakatan adalah tempat untuk melaksanakan pembinaan narapidana dan anak didik pemasyarakatan (UU RI No. 12 Th. 1995 tentang Pemasyarakatan Pasal 1 ayat 2). Lapas Kelas II Metro ini yang beralamat : Jl.A.Yani No.213 Kel.Iringmulyo KecamatanMetro Timur Kota Metro 34111, dengan Kepala lapas bapak maisar, yang dihuni dihuni oleh 449 orang, Email: lapasmetro_ pengaduan@yahoo.co.id, Telepon: 0725-41709.

\section{Hasil Penelitian dan Pembahasan}

1. Program bimbingan agama Islam di Lapas Kelas II Metro.

${ }^{23}$ Zakiah Daradjat, Kesehatan Mental, h. 11.

24 Soerjono Soekanto, Sosiologi Suatu Pengantar (Jakarta: Rajawali Press, 2002), h. 3. 
Dari hasil penelitian pada tahap admisi dan orientasi sangat penting untuk penyusunan program pembinaan selanjutnya, mengenai pendidikan atau pekerjaan apa yang cocok, dan dimana harus dibina. Tahap admisi dan orientasi berjalan paling lama satu bulan.

Masa admisi orientasi ini narapidana diberikan penerangan-penerangan mengenai:

a. Peraturan tata tertib dan disiplin yang berlaku dalam lembaga pemasyarakatan

b. Program kerja lembaga pemasyarakatan dalam pembinaan narapidana

c. Tata cara dan prosedur pengajuan keluhan narapidana

d. Hak-hak dan kewajiban yang patut diperhatikan oleh setiap narapidana selama mengikuti program kerja lembaga pemasyarakatan

e. Pemberian nama petugas lembaga pemasyarakatan yang akan menjadi walinya selama menjalani pembinaan

f. Kunjungan keluarga ke lembaga pemasyarakatan

Untuk pelaksanaan pembinaan ini, Lembaga Pemasyarakatan Kelas II A Metro menyelenggarakannya dua hari dalam satu minggu, setiap hari Senin dan Rabu bagi yang beragama Islam dan setiap Kamis dan Sabtu bagi yang beragama Nasrani. Kegiatan ini dilaksanakan oleh Lembaga Pemasyarakatan bekerjasama dengan dinas terkait yaitu Kementrian Agama dan Dewan Gereja Indonesia/Majelis Wali Gereja Indonesia. Untuk lebih jelasnya dapat dilihat dari tabel berikut ini:

Tabel 2. Pelaksanaan Pembinaan Kesadaran Beragama

\begin{tabular}{|c|c|c|c|c|}
\hline No. & Pendidikan Agama & Lamanya 1 Minggu & Waktu (Jam) & F (n-6) \\
\hline 1. & Islam & 2 Hari & 2 & 4 \\
\hline 2. & Kristen & 2 Hari & 2 & 2 \\
\hline
\end{tabular}

Sumber: Data lapangan diolah, Tahun 2016

Jika dilihat tabel di atas, seluruh responden baik yang beragama Islam maupun yang beragama Kristen telah diberikan pendidikan agama. Dengan demikian pembinaan kesadaran beragama yang merupakan hak para narapidana telah 
terlaksana sesuai dengan ketentuan yang ada. Pembinaan seperti ini adalah sesuatu bentuk pembinaan yang diberikan kepada narapidana agar mereka dapat membedakan mana yang benar dan mana yang salah menurut ketentuan aturan yang digariskan oleh agama mereka masing-masing atau dengan kata lain agar dapat menjadi manusia yang taat kepada peraturan agama.

\section{Proses bimbingan Islam di Lapas Kelas 11 Metro}

Proses bimbingan Islam Dalam Kerangka Pembinaan Narapidana Di Lembaga Pemasyarakatan Kelas II B Metro dilakukan secara terencana, terarah dan terpadu. Terencana, yaitu implementasi ajaran agama Islam dalam kerangka pembinaan bagi narapidana di Lembaga Pemasyarakatan Kelas II B Metro yang antara lain meliputi kegiatan sholat dan pengajian diselenggarakan secara terjadwal setiap hari.Baik terjadwal mengenai waktu maupun materinya.

Dalam Proses bimbingan Islam di Lapas Kelas 11 Metro tentunya ada faktor pendukung dan penghambat. Terkait dengan pelaksanaan bimbingan ajaran agama Islam di Lembaga Pemasyarakatan Kelas II B Metro yang berkapasitas 234 orang yang sekarang dihuni oleh 569 narapidana tersebut dalam melakukan pembinaan terdapat beberapa faktor pendukung, antara lain telah bekerjasama dengan berbagai instansi, baik instansi pemerintah maupun instansi non pemerintah. Instansi Pemerintah antara lain Rumah Sakit Umum A. Yani Metro, Kantor Kementrian Agama Kota Metro, Universitas Muhammadiyah Metro, IAIN Metro dan lainntya.

Dalam hal ini peneliti hanya meneliti tentang bimbingan Islam di lapas II A Metro untuk warga binaan .

1. Tujuan pelaksanaan bimbingan Islam di Lapas lapas II A Metro

Dari penelitian yang penulis lakukan tentang tujuan pelaksanaan pendidikan agama Islam di lapas II A Metro diperoleh hasil sebagai berikut:

Rohmadi MH selaku kasi binadik tujuan bimbingan Islam di lapas adalah untuk meningkatkan keimanan dan ketaqwaan warga binaan, agar warga binaan dapat instropeksi diri, juga untuk memberikan bekal dan pedoman hidup beragama agar warga binaan dapat menyadari kesalahannya dan memperbaiki diri untuk tidak 
mengulangi kesalahannya, selain itu untuk mempersipakan warga binaan untuk dapat berinteraksi secara sehat dengan masyarakat sehingga mereka dapat berperan kembali sebagai warga masyarakat yang baik ${ }^{25}$.

2. Materi dan Metode pelaksanaan bimbingan Islam di Lapas lapas II A Metro .

Berdasarkan studi dokumentasi dan dari wawancara yang peneliti lakukan tentang materi pendidikan agama Islam di Lapas II Metro untuk warga binaan umum, diperoleh hasilsebagai berikut:1) Materi tauhid, 2) Materi akhlak,c 3) Materi baca tulis Al-Qur'an, 4) Materi Penyuluhan Hukum, 5) Materi Tafsir, 6) Materi Hadits, 7 )Materi Tasawuf. Dari observasi peneliti, dalam penyapaian materipembimbing keagamaan atau Ustadz hanya menggunakan metode ceramah, dan menggunakan metode qiro'ah pada materi BTA. Hal tersebut diperkuat oleh Bapak Hidayat yang mengatakan: “Tergantung materi apa yang disampaikan. Kalau BTA biasanya menggunkan Teknik muthala'ah atau qiro'ah." 26 Sementara itu Bapak Rohmadi mengatakan: "Berkaitan dengan masalah fiqh. Ada materi yang disampaiakan dengan metodenya biasa dengan ceramah. Tapi ada juga materi yang disampaikan dengan metode pembiasaanseperti tentang sholat."27.

Pada metode nasehat ini, peneliti memperoleh data dari pengamatan yang penulis lakukan sewaktu observasi di Lapas II Metro. Saat peneliti mengikuti pelaksanaan pendidikan agama Islam di Lapas, pembimbing keagamaan (Ustadz) bukan hanya memberikan penjelasan-penjelasan tentang materi tetapi juga memberikan nasehat kepada warga binaan untuk dapat menjadi orang yang lebih baik lagi. Dari penelitian yang penulis lakukan tentang metode pelaksanaan pendidikan agama Islam berupa untuk wargabinaan umum di Lapas Metro diperoleh hasil sebagai berikut:

\footnotetext{
25 Wawancara dengan Rohmadi, KASIBINANDIK, 19 Oktober 2016

26 Wawancara dengan Bapak Hidayat, Pembina Keamanan Lapas, 28 Oktober 2016

27 Wawancara dengan Rohmadi, KASIBINANDIK, 19 Oktober 2016
} 
1) Metode Ceramah. Metode ceramah ini digunakan pada mayoritas materi pendidikan agama Islam di Lapas. Seperti dalam materi tauhid, materi akhlak, materi fiqh, materi tafsir, materi hadits dan materi tasawuf.

2) Metode Qiro'ah. Metode Qiro'ah ini digunakan pada materi BTA.Karena dalam materi BTA warga binaan tidak hanya dituntut untuk mendengarkan pembimbing tetapi juga membaca dan menirukan apa yang diucapkan pembimbing.

3) Metode Pembiasaan. Metode pembiasaan ini adalah sebuah metode yang digunakan untuk mebiasakan warga binaan pada hal-hal baik. Seperti sholat lima waktu berjamaah, membaca Al-Qur'an, dan berprilaku sopan.

4) Metode Nasehat. Metode nasehat ini digunakan pada seluruh materi. Seperti dalam materi tauhid, materi BTA, materi akhlak, materi fiqh, materi tafsir, materi haditsdan materi tasawuf. Karena dalam penyampaian pokok bahasan tertentu tertapat bagian-bagian atau waktu yang tepat untuk pembimbing memberikan kepada warga binaan. Seperti materi tentang taubat, makanan yang halal dan haram, tentang judi dan khamar, tentang keutamaan sholat dan tentang keesaan Allah. ${ }^{28}$

3. Hambatan dan Solusi dalam pelaksanaan bimbingan Islam di Lapas lapas II A Metro Lampung.

Ada beberapa faktor pendukung lain dalam pembinaan agama Islam bagi narapidana di Lembaga Pemasyarakatan Kelas II B Metro yaitu:

a. Masjid.

Dengan adanya masjid yang terletak di dalam blok semua penghuni Lembaga Pemasyarakatan Kelas II B Metro mempunyai ruang khusus yang dapat digunakan sebagai tempat ibadah danuntuk kegiatan lainnya.

b. Alat perlengkapan sholat

Agar proses implementasi ajaran Agama Islam dapat berjalan dengan baik adapun alat perlengkapan yang disediakan oleh Lembaga Pemasyarakatan Kelas II B Metro sebagai sarana pelengkap sholat. Seperti sajadah dan karpet.

28 Dokumentasi kurikulum PAI Lapas Pekalongan, 23 Oktober 2016. 
c. Perlengkapan belajar mengajar

Adanya pembinaan narapidana dengan kegiatan-kegiatan keagamaan yang dilakukan oleh Lembaga Pemasyarakatan Kelas II B Metro seperti praktek dakwah, belajar baca tulis Al-Qur'an dan sebagainya maka Lembaga Pemasyarakatan Kelas II B Metro juga menyediakan perlengkapan belajar mengajar sebagai sarana pendukung kegiatan tersebut, yaitu dengan adanya meja kecil untuk belajar baca tulis Al-Qur'an, papan tulis, spidol, penghapus, juz Amma, iqro dan Al-Qur'an.

Faktor Penghambat dan solusi dalam Pelaksanaan bimbingan Islam Dalam Kerangka Pembinaan Narapidana Di Lembaga Pemasyarakatan Kelas II B Metro.

a. keterbatasan bangunan

Lembaga Pemasyarakatan Kelas II B Metro yang terletak di tengahtengah kota Metro sangat mempengaruhi jumlah bangunannya. Dengan lahan Lembaga Pemasyarakatan yang minim maka bangunan yang dimiliki oleh Lembaga Pemasyarakatan sangat terbatas.

b. Sarana atau Prasarana

Untuk menunjang pembinaan yang baik maka perlu didukung dengan sarana dan prasarana yang cukup memadai, pada Lembaga Pemasyarakatan Kelas II B Metro sarana dan prasarana yang menunjang program pembinaan masih dirasa sangat kurang.

c. Kualitas dan kuantitas petugas

Dari seluruh pegawai yang berjumlah 78.orang tidak ada satu pegawaipun di Lembaga Pemasyarakatan Kelas II B Metro yang berlatar belakang pendidikan Sarjana Agama Islam, sehingga dalam melakukan pembinaan ajaran Agama Islam sangat kurang maksimal karena hanya dilakukan oleh petugas yang latar belakang agamanya sangat terbatas, maka solusinya Lembaga Pemasyarakatan Kelas II B Metro.

d. Partisipasi Masyarakat

Selama ini peran masyarakat dalam mendukung program pembinaan yang dijalankan oleh pihak Lembaga Pemasyarakatan dirasa masih sangat 
kurang, padahal salah satu unsur yang paling menentukan dari keberhasilan sebuah pembinaan adalah dengan adanya partisipasi dari masyarakat, oleh karena itu, solusinya untuk menyikapi kurangnya partisipasi dari masyarakat setempat dalam mensukseskan program pembinaan, pihak Lembaga Pemasyarakatan selalu mengadakan pembinaan dan penyuluhan kepada masyarakat sekitar agar lebih peduli pada proses reintegrasi narapidana

Faktor-faktor penghambat implementasi pelaksanaan hak-hak narapidana di Lembaga Pemasyarakatan Kelas II A Metro, sebagai berikut:

a. Faktor Hukum (Perundang-undangan)

Berbagai macam hak narapidana yang telah disebutkan di atas, dalam pelaksanaannya membutuhkan syarat administratif yang mutlak harus ada, yaitu petikan putusan (vonis) pengadilan dan berita acara pelaksanaan putusan pengadilan yang dibuat oleh jaksa sebagai eksekutor. Adanya petikan putusan menjadi bukti formal bahwa perkara yang dikenakan terhadap seorang terdakwa telah dikenakan suatu putusan pidana oleh pengadilan, artinya tanpa adanya petikan vonis, maka putusan pengadilan yang menjatuhkan suatu pidana belum dapat dilaksanakan.

Pembuatan dan pendistribusian petikan putusan pengadilan diatur dalam Pasal 226 KUHAP, yang secara lengkap berbunyi sebagai berikut:

(1) Petikan surat putusan diberikan kepada terdakwa atau penasehat hukumnya setelah putusan diucapkan;

(2) Salinan surat putusan pengadilan diberikan kepada penuntut umum dan penyidik, sedangkan kepada terdakwa atau penasehat hukumnya diberikan atas permitaan;

(3) Salinan surat putusan pengadilan hanya boleh diberikan kepada orang lain dengan izin ketua pengadilan setelah mempertimbangkan kepentingan dari permintaan tersebut.

b. Faktor Penegak Hukum

Pembinaan narapidana terkait erat dengan jumlah petugas Lembaga Pemasyarakatan. Jumlah petugas yang hanya 59 orang dirasa belum 
mencukupi untuk kapasitas 528 orang narapidana. Apalagi dengan jumlah petugas Pembina yang hanya 27 orang, sangat sulit untuk dapat membina seluruh narapidana yang berjumlah 528 orang. Belum lagi didasarkan pada tugas dari petugas pemasyarakatan yang harus membina dan mengawasi warga binaan selama 24 jam penuh yang tidak sama dengan jam kerja pegawai negeri pada umumnya. Tugas mereka amat berat dan diperlukan pengabdian tinggi serta dibutuhkan keahlian dan pendidikan yang memadai bagi petugas karena petugas setiap hari menghadapi berbagai macam tingkah para narapidana. Oleh karena itu untuk mengatasi keterbatasan tersebut bias dilakukan dengan cara meningaktkan prestasi kerja, peningkatan pendidikan bagi petugas, mengikuti penataran dan pelatihan dan yang tidak kalah pentingnya mengadakan penerimaan personil atau petugas pemasyarakatan dengan selektif dalam rangka mencari petugas yang berkualitas.

\section{c. Faktor Sarana dan Fasilitas}

Tempat praktek latihan kerja dan keterampilan serta ruang bengkel yang sangat terbatas merupakan sisi lain sebagai faktor penghambat dalam proses pembinaan, belum lagi ditambah peralatan yang kurang lengkap dan tidak memadai. Demikian pula minimnya fasilitas poliklinik Lembaga Pemasyarakatan membuat pelayanan kesehatan menjadi tidak optimal. Ruang poliklinik hanya dilengkapi peralatan medis sederhana dan kurang memadai serta kurangnya persediaan obat-obatan disamping terbatasnya tenaga medis yang hanya dua orang perawat dan seorang dokter umum melayani 528 orang narapidana. Fasilitas tempat ibadah yang hanya berukuran $7 \times 7 \mathrm{~m}$ dirasakan sudah tidak memadai dan tidak mencukupi untuk menampung para narapidana yang akan melakukan ibadah terutama untuk shalat Jum'at dan kegiatan-kegiatan pembinaan keagamaan.

\section{Simpulan}

Dari uraian di atas maka dapat diambil beberapa simpulan dalam penelitian ini yaitu: Pembinaan Agama Islam bagi narapidana diharapkan dapat menumbuhkan 
kesadaran pada narapidana agar tidak mmengulangi lagi perbuatannya dan kembali ke jalan yang benar, jalan yang sesuai aturan dan diridhoi oleh Allah SWT.

Kegiatan pembinaan Agama Islam bagi narapidana di Lembaga Pemasyarakatan Kelas II B Metro dapat dikatakan berhasil. Sebagaimana hasil dari penelitian penulis bahwa hal tersebut dapat dilihat dari indikator-indikator keberhasilan pada diri narapidana itu sendiri, di mana sebagian besar warga binaan yang dulunya sebelum masuk ke dalam Lembaga Pemasyarakatan Kelas II B Metro tidak pernah melaksanakan sholat, tidak bisa membaca Al-Qur'an, bahkan tidak mengenal agama sekarang dengan sangat aktif selalu mengikuti kegiatan-kegiatan keagamaan seperti sholat berjamaah, pengajian dan ceramah agama yang diselenggarakan oleh Lembaga Pemasyarakatan Kelas II B Metro. Dengan demikian terbukti bahwa Lembaga.

Pemasyarakatan Kelas II B Metro telah berhasil membuat penghuninya meyakini ajaran agama yang dianutnya dan menyadari bahwa agama adalah suatu kebutuhan yang sangat penting bagi manusia dan selalu berusaha menjadi manusia yang lebih baik lagi dari sebelumnya. Dalam pelaksanaannya, kegiatan pembinaan Agama Islam bagi narapidana yang ada di Lembaga Pemasyarakatan Kelas IIB Metro tidak terlepas dari faktor-faktor penghambat jalannya pembinaan di mana faktorfaktor tersebut antara lain sarana atau fasilitas yang belum memadai, ' ohnya seperti belum adanya perpustakaan, kurangnya jumlah buku-buku bac itang keIslaman, petugas yang kurang profesional dan partisipasi dari masyaraкat уang masih kurang.

\section{DAFTAR PUSTAKA}

Faqih, Rahim, and Aunur. Bimbingan Dan Konseling Dalam Islam. Yogyakarta: UII Press, 2001.

Kartono. Psikologi Anak. Bandung: Alumni, 1982.

Khoirudin Nasution. Pengantar Studi Islam. Yogyakarta: Academia, 2004.

M. Arifin. Pokok-Pokok Pikiran Tentang Bimbingan Penyuluhan Agama. Jakarta: Bulan Bintang, 1977. 
M. Mashur Amin. Metode Dakwah Islamiyah. Yogyakarta: Sumbangsih, 1980.

M. Quraish Shihab. A-Qur'an: Fungsi Dan Peran Wahyu Dalam Kehidupan Masyarakat. Bandung: Mizan Pustaka, 2007.

Musfir. Konseling Terapi. Jakarta: Gema Insani, 2005.

Nasrudin Razak. Dienul Islam. Bandung: Al-Maarif, 1996.

Peter Salim, and Yenny Salim. Kamus Bahasa Indonesia Kontemporer. Jakarta: Modern English Press, 1991.

Salcha Hatras. Konsep Dasar Bimbingan Dan Konseling. Surakarta: FKIP UNS, 1999.

Singgih D Gunarsa. Konseling Dan Psikoterapi. Jakarta: Gunung Mulia, 1992.

Soerjono Soekanto. Sosiologi Suatu Pengantar. Jakarta: Rajawali Press, 2002.

Tim Penyusun Kamus Pusat Pembinaan dan Pengembangan Bahasa. Kamus Besar Bahasa Indonesia. Jakarta: Balai Pustaka, 2004.

Wiryo Setiana. Patologi Sosial. Bandung: Mimbar Pustaka, 2012.

W.S. Winkel. Bimbingan Dan Konseling Di Institusi Pendidikan. Jakarta: Gramedia, 1997.

- - - Bimbingan Dan Konseling Di Sekolah. Jakarta: Gramedia, 1984.

Zakiah Daradjat. Kesehatan Mental. Jakarta: Gunung Agung, 2006.

\section{Perundang-Undangan}

Undang-Undang Dasar 1945.

Undang-Undang Nomor 1 Tahun 1946 Tentang Kitab Undang-Undang Hukum Pidana.

Undang-Undang Nomor 8 Tahun 1981 Tentang Kitab Undang-Undang Hukum Acara Pidana.

Undang-Undang Nomor 12 Tahun 1995 Tentang Pemasyarakatan.

Peraturan Pemerintah Nomor 27 Tahun 1983 Tentang Pelaksanaan KUHAP.

Peraturan Pemerintah Nomor 31 Tahun 1999 Tentang Pembinaan dan Pembimbingan Warga Binaan Pemasyarakatan. 
Peraturan Pemerintah Nomor 32 Tahun 1999 Tentang Syarat dan Tata cara Pelaksanaan Hak Warga Binaan Pemasyarakatan.

Keputusan Presiden RI No. 174 Tahun 1999 tentang Remisi. Peraturan Menteri Hukum dan HAM RI No. M.PK.01.10 Tahun 2007 tentang Syarat dan Tata Cara Pelaksanaan Asimilasi, Pembebasan Bersyarat, Cuti Menjelang Bebas dan Cuti Bersyarat. 